\title{
Antibacterial Zinc Oxide Nanoparticle Coating of Polyester Fabrics
}

\author{
Claudia Rode ${ }^{2}$, Michael Zieger ${ }^{1}$, Ralf Wyrwa², Susanne Thein ${ }^{2}$, Cornelia Wiegand1, \\ Monika Weiser ${ }^{3}$, Andreas Ludwig4, Dirk Wehner ${ }^{4}$, Uta-Christina Hipler ${ }^{1}$ \\ ${ }^{1}$ Department of Dermatology, Jena University Hospital, Jena, Germany \\ ${ }^{2}$ INNOVENT e.V., Biomaterials Department, Jena, Germany \\ ${ }^{3}$ Textile Research Institute Thuringia-Vogtland, Greiz, Germany \\ ${ }^{4}$ Thorey Gera Textilveredelung GmbH, Gera, Germany \\ Email: ${ }^{*}$ cr@innovent-jena.de
}

Received 29 June 2015; accepted 16 August 2015; published 19 August 2015

Copyright (C) 2015 by authors and Scientific Research Publishing Inc.

This work is licensed under the Creative Commons Attribution International License (CC BY).

http://creativecommons.org/licenses/by/4.0/

c) (i) Open Access

\begin{abstract}
Polyester knitted fabrics have been equipped with antibacterial properties by coating with aqueous suspensions of zinc oxide (ZnO) with different particle diameters. It can be shown that the antibacterial efficacy against Staphylococcus aureus and Klebsiella pneumonia and the permanence of the coating after defined washing cycles depends on the composition of the $\mathrm{ZnO}$ dispersion. To improve the wettability of the textile, the combustion chemical vapor deposition (CCVD) is used to generate a hydrophilic nano layer of a hydroxyl terminated silicon network on the surface of the textiles. The comparison of CCVD-treated and untreated polyester samples does not show differences in the antibacterial activity. The influence of the coating in terms of amount and particle size of ZnO on the viability and proliferation of 3T3 mouse fibroblast cells is examined. A particle content of a maximum of $20 \mu \mathrm{gnO} / \mathrm{cm}^{2}$ is found to be cytocompatible for coating of textiles.
\end{abstract}

\section{Keywords}

Antibacterial, Textile, ZnO Nanoparticles, Cytocompatibility

\section{Introduction}

Omnipresent colonization of material surfaces, especially by bacteria, is an undesired occurrence in the technical sector as well as in everyday life and can be life-threatening in the clinical area. In the case of used clothing and other fabrics, bacterial colonization causes unpleasant odors or infections. In recent years, mainly technical tex-

"Corresponding author.

How to cite this paper: Rode, C., Zieger, M., Wyrwa, R., Thein, S., Wiegand, C., Weiser, M., Ludwig, A., Wehner, D. and Hipler, U.-C. (2015) Antibacterial Zinc Oxide Nanoparticle Coating of Polyester Fabrics. Journal of Textile Science and Technology, 1, 65-74. http://dx.doi.org/10.4236/itst.2015.12007 
tiles are equipped with antibacterial properties, but nowadays the growing awareness of health and hygiene increases the demand for antibacterial materials in a wide range of applications including medicine, medical care, protective clothing, and household as well as sport and leisure time. The use of several substances for reducing bacterial colonization on textile surfaces have been reported including positively charged molecules [1]-[4], silver [4]-[7], copper [8], triazin derivatives [9] [10], chitosan [3] [11] [12], or triclosan [3]. Because of existing disadvantages like toxicity [13], high costs or issues of bacterial resistance of the mentioned examples [14]-[16], we decide to apply zinc oxide (ZnO) as antimicrobial agent [17]-[19]. In several studies the antimicrobial effect of zinc oxide coatings against different bacteria can be already verified [20]-[23].

For the development of antibacterial textiles for applications on a large scale, e.g. in medicine and for wearing apparel, it is necessary to find the optimum of $\mathrm{ZnO}$ concentration to effectively combat bacteria while preventing cytotoxic effects. Therefore, the main focus of our study is the investigation of the correlation between the $\mathrm{ZnO}$ content, the antibacterial activity and the cytocompatibility of $\mathrm{ZnO}$ coated textiles. Furthermore, our research addresses the improvement of the coated polyester regarding the optical appearance and especially of the permanence of the antibacterial effect. For that reason the CCVD process is applied to enhance the adhesive strength between the coating and the textile surface. The antibacterial activity of $\mathrm{ZnO}$ nanoparticle coated textiles has been proven using the nosocomial pathogens Staphylococcus aureus and Klebsiella pneumoniae.

\section{Materials and Methods}

\subsection{Materials}

Powder of ZnO nanoparticles was obtained from ABCR (Karlsruhe, Germany, article no. AB 255364) and IBUtec advanced materials AG (Weimar, Germany). In addition, $\mathrm{ZnO}$ nanoparticle dispersion in water $(40 \%$ (w/w)) was obtained from IBUtec.

Impranil DLU (aliphatic polycarbonate ester polyether polyurethane dispersion in water, $60 \%$ solid content), Baybond PU 406 (non-ionic polyurethane dispersion in water, 34.5\% solid content) and Desmodur DN (aliphatic poly-isocyanate) were provided by Bayer Material Science AG (Leverkusen, Germany).

3T3 mouse embryonic fibroblasts were purchased from LGC Standards GmbH (Wesel, Germany).

Staphylococcus aureus ATCC 6538 and Klebsiella pneumoniae ATCC 4352 were obtained from the Leibniz Institute DSMZ-German Collection of Microorganisms and Cell Cultures (Braunschweig, Germany). For cultivation of bacteria, special peptone and "lab-lemco" powder for preparation of Caso bouillon and bacteriological agar were purchased from Oxoid Deutschland GmbH (Wesel, Germany). Columbia agar plates with 5\% sheep blood were acquired from bioMérieux Deutschland GmbH (Nürtingen, Germany). Physiological NaCl solution (0.9\%) was purchased from Fresenius Kabi Deutschland AG (Bad Homburg, Germany). Tween 20 was obtained from Carl Roth GmbH (Karlsruhe, Germany).

Polyester knitted fabrics were provided by Thorey Gera Textilveredelung GmbH (Gera, Germany).

\subsection{Coating Process}

Activation of the polyester was performed using the CCVD technique with a custom-made winding construction with two of four burners and a limited coating width of $30 \mathrm{~cm}$. For the process, an air flow of $600 \mathrm{~L} / \mathrm{min}$ was used. The air/gas ratio was adjusted to 18.8. The precursor (30\% hexamethyldisiloxane (HMDSO) in isopropanol) was added at a flow rate of $5.5 \mathrm{~mL} / \mathrm{min}$. The speed of sweep was $50 \mathrm{~m} / \mathrm{min}$ and the temperature of the guide rollers was kept at $50^{\circ} \mathrm{C}$.

For preparation of the coating suspension, the $\mathrm{ZnO}$ powder (ABCR) or the $40 \%$ (w/w) $\mathrm{ZnO}$ suspension (IBUtec) were diluted with water to obtain the desired concentration of $0.25 \%$ to $1 \%$ of $\mathrm{ZnO}$. ABCR nanoparticles were used as received without disaggregating. To the suspension $2 \%$ to $5 \%(\mathrm{w} / \mathrm{w})$ of a binder (Baybond PU and Impranil DLU, respectively) was added.

For laboratory scale a culture dish was used for dip coating of the textiles. After storing the textiles for 5 min in the coating solution, they were removed and heated to $80^{\circ} \mathrm{C}$ for $15 \mathrm{~min}$ and then heated to $150^{\circ} \mathrm{C}$ for $30 \mathrm{~min}$. During the coating procedure stirring at $750 \mathrm{rpm}$ was necessary to avoid sedimentation of the nanoparticles.

The antibacterial coating in industrial scale was realized by a foulard machine (model HVF, Mathis AG, Oberhasli, Switzerland). Stirring was not possible during the coating procedure. The polyester was run with 100 $\mathrm{cm} / \mathrm{min}$ through the $\mathrm{ZnO}$ suspension and squeezed at $0.3 \mathrm{MPa}$. Afterwards it was dried for $2 \mathrm{~min}$ at $100^{\circ} \mathrm{C}$ and 
the crosslinking reaction was performed by heating in a second step for $1.5 \mathrm{~min}$ at $150^{\circ} \mathrm{C}$ (Labdryer, Mathis AG, Oberhasli, Switzerland).

\subsection{Characterization}

Scanning electron microscopy (Supra 55V, Carl Zeiss SMT, Oberkochen, Germany) was used to investigate the size of the nanoparticles and the surface of coated polyester fabrics. Qualitative SEM-EDX analysis was carried out using the Quantax system with a Si (Li) detector (Röntec, Berlin, Germany). The samples were vapor coated with carbon and activated by an electron beam of $15 \mathrm{keV}$.

The zinc content of coated samples was determined by complexometric titration with a $0.1 \mathrm{M}$ aqueous solution of ethylenediaminetetraacetic acid disodium salt (Aldrich, Steinheim, Germany). The zinc oxide on sample surface was dissolved by the use of $18 \%$ hydrochloric acid before analysis.

\subsection{Washing Process}

To evaluate the quality of antimicrobially finished fabrics, the permanence against mechanical and chemical stress was studied applying washing and drying cycles. The minimum number of cycles was defined corresponding to the designated purpose. The investigation was performed using an aqueous detergent solution as well as subsequent rinsing and drying steps in a modified wash test according to DIN EN ISO 105-C10, method A.

The washing tester "Linitest" was used for determining the wash durability of the fabrics. Two specimens with a size of $10 \mathrm{~cm} \times 4 \mathrm{~cm}$ were treated in a steel container for $30 \mathrm{~min}$ at $40^{\circ} \mathrm{C}$ using a liquor ratio (specimen: liquor) of $50 \mathrm{~g} / \mathrm{L}$. The used washing liquor contained $5 \mathrm{~g} / \mathrm{L}$ of a detergent.

The samples were transferred to a container with $2 \mathrm{~L}$ of distilled water and rinsed by careful moving. The samples were then rinsed under running cold water and dried in the air.

\subsection{Antibacterial Activity}

Testing for antibacterial activity was carried out in accordance to the Japanese Industrial Standard (JIS L 1902:2002, “Testing method for antibacterial activity of textiles”) as reported previously [24]. In brief, S. aureus or K. pneumoniae were cultivated in caso-bouillon at $37^{\circ} \mathrm{C}$ for $18 \mathrm{~h}$ under aerobic conditions. For experiments, bacteria cultures were diluted with Caso bouillon to an inoculum concentration of $5 \times 10^{5} \mathrm{cfu} / \mathrm{mL}$. $400 \mathrm{mg} \mathrm{sam}-$ ples of the test material were inoculated with $200 \mu \mathrm{L}$ test microbe inoculum and incubated at $37^{\circ} \mathrm{C}$ for $24 \mathrm{~h}$ under aerobic conditions. Untreated polyester was used as negative control. For determination of the germ number after $24 \mathrm{~h}$, samples were extracted in $0.9 \% \mathrm{NaCl}$ solution supplemented with $0.2 \%$ tween 20 . Serial dilutions were plated onto Columbia agar plates and incubated for $24 \mathrm{~h}$ at $37^{\circ} \mathrm{C}$. Afterward, colonies were calculated, total cfu (colony forming units) estimated, and growth reduction assessed according to Equation (1). According to JIS L 1902, a logarithmic microbial growth reduction of less than 0.5 denotes no antibacterial activity. Values from 0.5 to 1 are estimated as a slight, values greater than 1 and less or equal to 3 as a significant, and a log reduction greater than 3 as a strong antibacterial activity.

$$
\log \text { growth reduction }(24 \mathrm{~h})=\log \mathrm{cfu}(\text { negative control })_{(24 \mathrm{~h})}-\log \mathrm{cfu}(\text { sample })_{(24 \mathrm{~h})}
$$

Equation (1) is the calculation of logarithmic microbial growth reduction.

\subsection{Cytocompatibility}

To assess cytocompatibility, the coated textiles and an uncoated sample as control were treated with $70 \%$ ethanol, washed with phosphate buffered saline (PBS) and seeded with 3 T3 mouse fibroblast cells at a cell density of about 25,000 cells $/ \mathrm{cm}^{2}$. The cells were cultured in Dulbecco's Modified Eagle Medium (DMEM) containing 10\% fetal bovine serum (FBS), $50 \mathrm{U} / \mathrm{mL}$ penicillin and $50 \mu \mathrm{g} / \mathrm{mL}$ streptomycin at $37^{\circ} \mathrm{C}$ under a $5 \% \mathrm{CO}_{2}$ atmosphere. The medium was renewed on day 2 . After 1 and 4 days the medium was changed against fluorescein diacetate (FDA) and GelRed ${ }^{\circledR}$. An Axiotech microscope (Zeiss, Jena, Germany) and a halogen lamp were used to monitor green and red fluorescence. Photomicrographs were recorded using a CCD microscope imaging system MP 5000 (Intas, Goettingen, Germany). Imaging was supported by Image-Pro Plus 5.1 software (Media Cybernetics, Silver Spring, USA). The total number of cells and the percentage of living cells were calculated after counting 
green fluorescent living cells and red fluorescent nuclei of dead cells.

\section{Results and Discussion}

\subsection{Nanoparticles}

The size of $\mathrm{ZnO}$ nanoparticles influences color, release of $\mathrm{Zn}$ ions, and particle distribution as well as roughness of the coated surface. Therefore, $\mathrm{ZnO}$ nanoparticles which are differ in particle size should be used to achieve optimal properties of an antibacterial coating. SEM-images of the applied nanoparticles of ABCR as well as IBUtec are shown in Figure 1.

It was found that the particles of the two suppliers vary distinctly in particle size. The mainly hexagonal prismatic $\mathrm{ZnO}$ NPs obtained from ABCR show a white color and a particle size in the range of 50 - $300 \mathrm{~nm}$ with scattered larger particles and aggregates. The $\mathrm{ZnO}$ particles obtained from IBUtec have a spherical shape with an average particle size of $10 \mathrm{~nm}$. Due to the small size these particles exhibit a brownish color.

\subsection{Coating Process}

For laboratory scale, polyester samples of $4 \mathrm{~cm} \times 10 \mathrm{~cm}$ were dip coated in a culture dish using $100 \mathrm{~mL}$ of an aqueous $\mathrm{ZnO}$ suspension $(0.3 \%-2.0 \%(\mathrm{w} / \mathrm{w}))$ containing Impranil DLU $(2 \%(\mathrm{w} / \mathrm{w}))$ as binder. The binder serves as a matrix for incorporating the $\mathrm{ZnO}$ nanoparticles improving the adhesion of $\mathrm{ZnO}$ to the hydrophobic textile surface. Complexometric analyses were performed at coatings with a concentration of $1.4 \%(\mathrm{w} / \mathrm{w}) \mathrm{ZnO}$. An average amount of $0.23 \mathrm{mg} \mathrm{ZnO} / \mathrm{cm}^{2}$ was found on these samples measured. Neither the particles used (ABCR or IBUtec) nor the activation with CCVD had an influence on the $\mathrm{ZnO}$ content of coated samples.

For coating procedures on industrial scale with a foulard machine a $\mathrm{ZnO}$ containing suspension $(0.04 \%-0.65 \%$ $(\mathrm{w} / \mathrm{w})$ ) was used. Figure 2 shows graphically the determined amounts of $\mathrm{ZnO}$ of coated polyester samples by complexometric titration.

No linear correlation was found between applied amount of ZnO powder used from ABCR and measured amount of $\mathrm{ZnO}$ of coated textiles (Figure 2(a)). The coating solution with $0.32 \% \mathrm{ZnO}$ content resulted in higher $\mathrm{ZnO}$ depositions on textile with CCVD pretreatment than the solution with $0.65 \% \mathrm{ZnO}$. This is most likely due to the deposition of the powder at the vessel bottom where it is not available during the coating procedure. This problem was avoided using the finely dispersed aqueous solution of $\mathrm{ZnO}$ nanoparticles from IBUtec (Figure 2(b)). Here, the measured amount of coating solution containing $0.5 \%$ of $\mathrm{ZnO}$ was found to be higher than the amount by using a $0.25 \% \mathrm{ZnO}$ solution. With CCVD an even distinctly higher quantity of $\mathrm{ZnO}$ could be achieved because of the higher absorption properties of the hydrophilic nano layer on the surface. However, due to the incompatibility of the $\mathrm{ZnO}$ nanoparticle suspension with the binder Impranil, the system had to be changed to use Baybond PU for coating. Additional use of the hardener Desmodur DN leads to further increase of the $\mathrm{ZnO}$ content on the textiles.
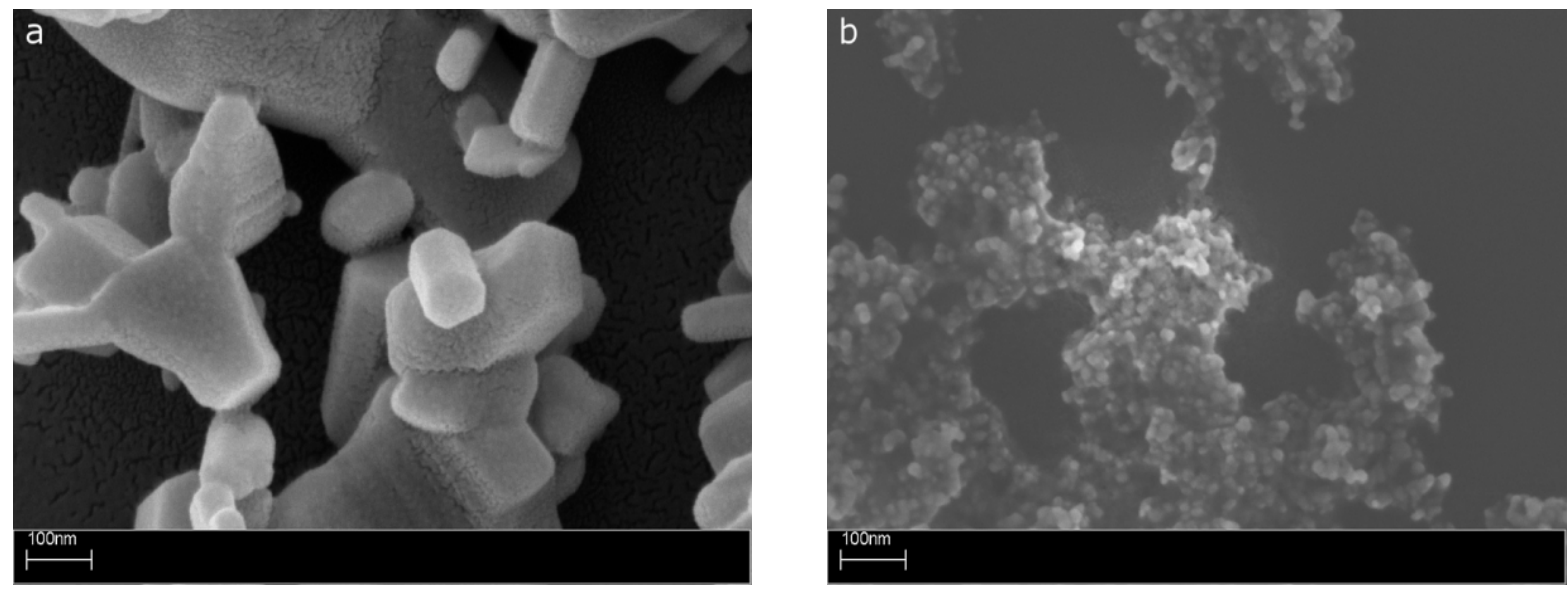

Figure 1. SEM images of ZnO nanoparticles obtained from ABCR (a) and IBUtec (b). 
The SEM images of laboratory coated textiles reveal the considerably higher adhesion of the $\mathrm{ZnO} / \mathrm{Impranil}$ system in the case of ABCR particles (Figure 3(a)) compared to the IBUtec particles (Figure 3(b)). Nevertheless, the qualitative EDX spectra (Figure 3(c), Figure 3(d)) show the presence of $\mathrm{Zn}$ in both coating systems. But in the case of ABCR ZnO particles palpable white deposits on the textiles could be observed (Figure 3(e)). However the appearance of the coating clearly favors IBUtec particles despite the slight brownish color (Figure $3(f)$ ) whereby spotting can be avoided by uniform application at industrial conditions with the foulard machine.

\subsection{Antibacterial Activity}

Figure 4 shows the antibacterial activity of laboratory coated polyester samples against Staphylococcus aureus and Klebsiella pneumoniae in vitro. Coating with ABCR ZnO particles and Impranil DLU as binder conveyed a strong antibacterial activity against $S$. aureus and $K$. pneumoniae up to 10 washing cycles (with and without CCVD pretreatment). In contrast, coating with IBUtec ZnO particles (with and without CCVD pretreatment) was less permanent and accomplished only a significant antibacterial effect against $S$. aureus and a slight antibacterial influence on $K$. pneumoniae after 10 washing cycles. After 50 washing cycles, textiles coated with $\mathrm{ZnO}$ nanoparticles of ABCR still obtained significant to strong results whereas coatings with ZnO particles of IBUtec showed a distinctly diminished antibacterial efficacy, though other studies showed an increasing activity with decreasing the particle size [22] [25]. We propose that the differences observed in the antibacterial activity of the different particles after several numbers of washing cycles are most likely due to a higher durability of ABCR ZnO particles on the polyester samples. Certainly the result based on the larger surface area of the IBUtec nanoparticles. These smaller particles will be dissolved faster during washing process.

Figure 5 shows the test results for the antimicrobial effect of the coated and washed polyester samples with the system ZnO (IBUtec, aqueous dispersion) and Baybond PU against Staphylococcus aureus and Klebsiella pneumoniae on industrial scale. Because of sedimentation of ABCR particles the IBUtec dispersion was used only for further studies. Simultaneously, the influences of the CCVD pretreatment and an additionally cross linking hardener (Desmodur DN) were investigated. No additional beneficial effect of the cross linking hardener on the washing stability of the coating could be observed. Pretreatment of the polyester samples with CCVD also showed no improvement of the permanence of the antibacterial activity. However, since pretreated textiles are more hydrophilic they can absorb more solution and the resulting amount of zinc oxide is higher than on untreated textiles. Figure 5 also shows that the washing stability by using Baybond PU is not as good as using Impranil DLU. Mainly slight antimicrobial effects could be observed after 10 washing cycles thus the influence of more than 10 washing cycles to the antimicrobial activity was not determined.

\subsection{Cytocompatibility}

The cytocompatibility of the coated polyester samples was studied by seeding 3 T3 fibroblast cells on the surface of the textiles and then estimating cell adhesion and viability using a FDA/GelRed ${ }^{\circledR}$ live/dead assay.

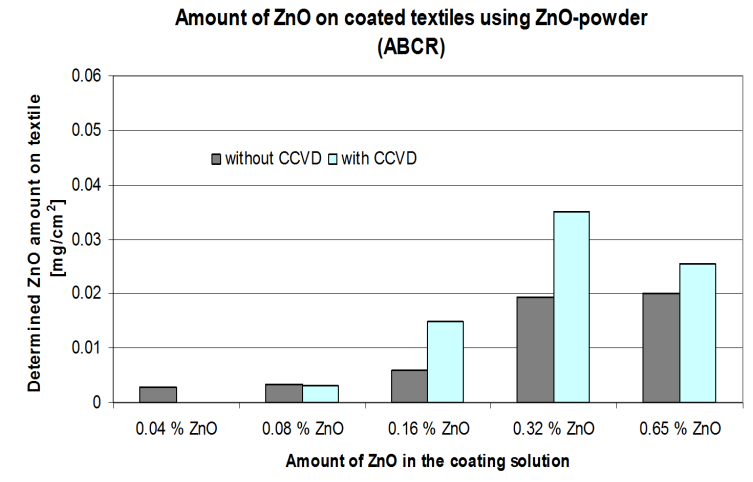

(a)

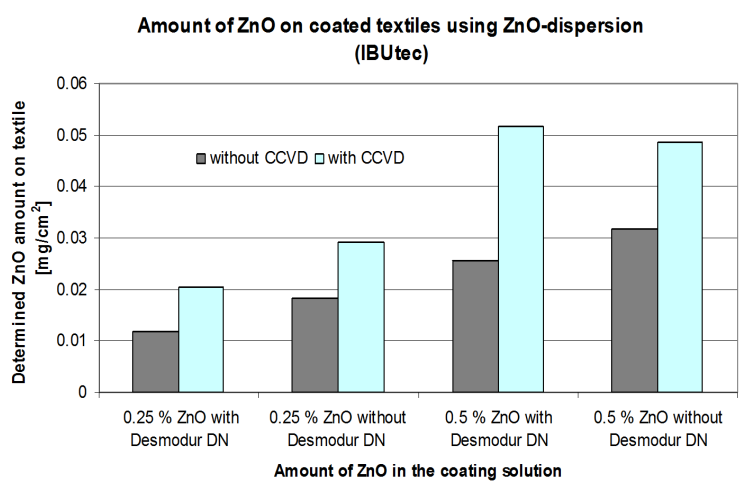

(b)

Figure 2. Measured amount of $\mathrm{ZnO}$ on industrial coated textiles using $\mathrm{ZnO}$ powder from ABCR and the binder Impranil DLU (a) as well as ZnO dispersion from IBUtec and Binder Baybond PU (b). 

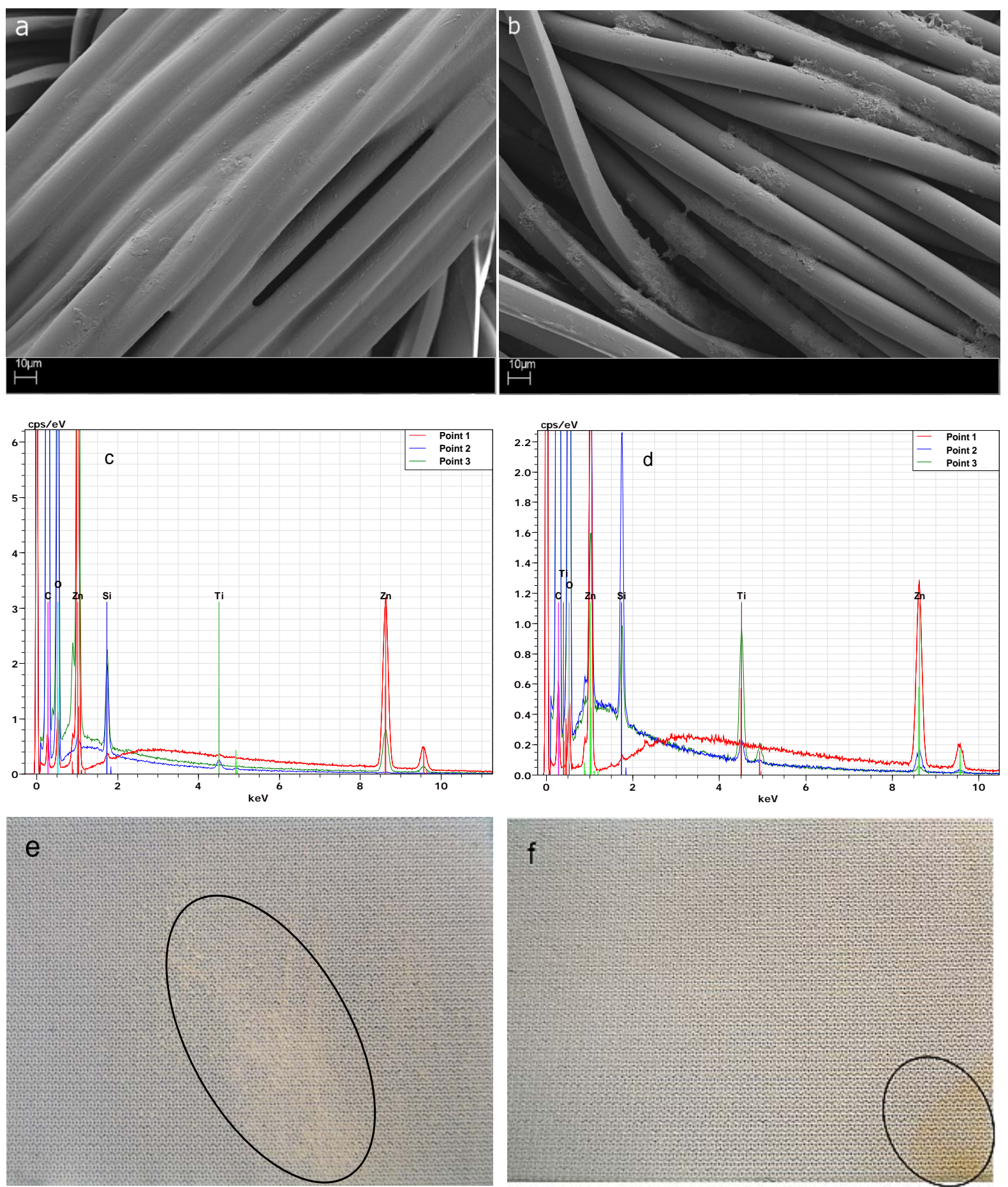

Figure 3. SEM images, EDX spectra (3 measurement points/sample) and photographic images of laboratory coated polyester samples with $\mathrm{ZnO}$ nanoparticles obtained from ABCR (a) (c) (e) and IBUtec (b) (d) (f).

Results shown here are exemplarily for the concentrations of $0 \%, 0.25 \%$ and $0.5 \% \mathrm{ZnO}$ (Figure 6). After an incubation period of 1 and 4 day, respectively, a large number of viable cells and only few dead ones could be detected on the control without coating. As can be seen on Figure 6(c), e that there are only a few viable cells after 1 day seeding on coated textile samples. At a concentration of $0.5 \% \mathrm{ZnO}$ in the coating solution (amount of about $50 \mu \mathrm{gnO} / \mathrm{cm}^{2}$ textile) there is a strong cytotoxicity after incubation of 1 day with $45 \%$ of dead cells and 


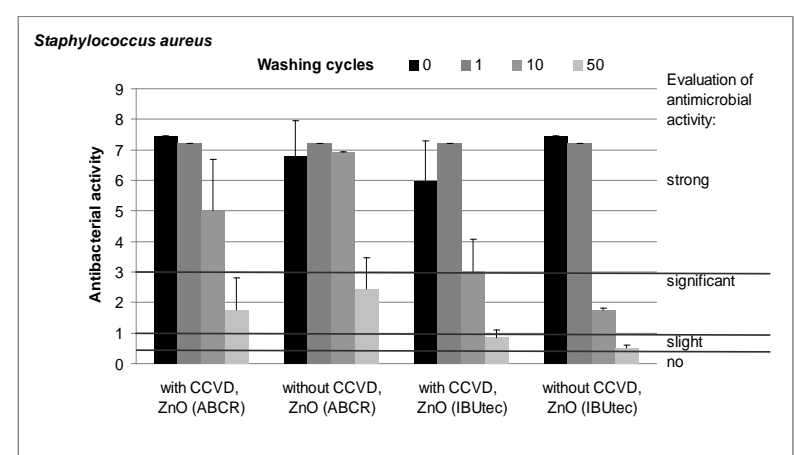

(a)

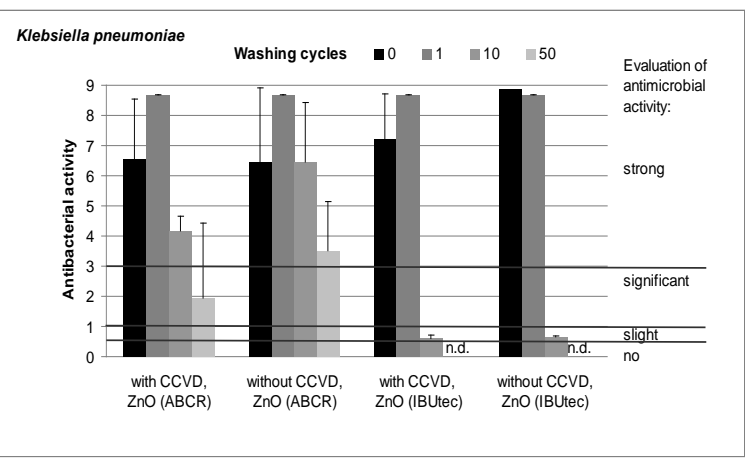

(b)

Figure 4. Antibacterial activity (log growth reduction) of laboratory coated and washed polyester textiles with $\mathrm{ZnO}$ and Impranil DLU, comparison of ABCR and IBUtec-particles (n. d. = not determined).

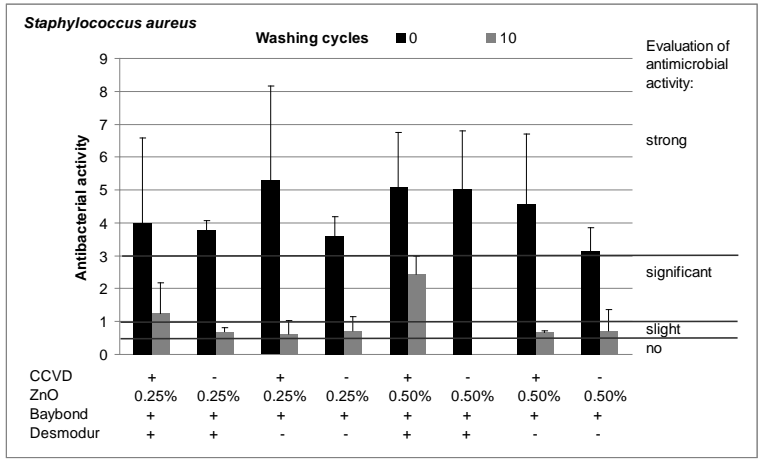

(a)

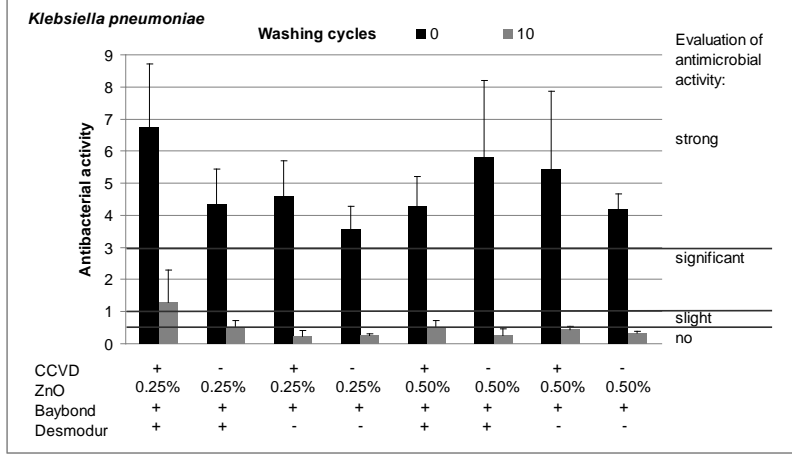

(b)

Figure 5. Antibacterial activity (log growth reduction) of industrial coated and washed polyester textiles with aqueous $\mathrm{ZnO}$ dispersion of IBUtec, Baybond PU and cross linking hardener Desmodur DN.

4 days with $23 \%$ of dead cells. The rising number of viable cells causes the decreasing number of dead cells. By changing the concentration of $\mathrm{ZnO}$ to $0.25 \%$ (amount of about $20 \mu \mathrm{g} \mathrm{ZnO} / \mathrm{cm}^{2}$ textile) we found cytotoxic effects only after 1 day of incubation with an amount of $22 \%$ of dead cells. After 4 days of seeding with 3 T3 fibroblast cells we found no cytotoxic effects of the coating with $3 \%$ of dead cells (Figure 6(f)). Nevertheless the total number of viable cells is 65\% in comparison with the uncoated textile sample. Investigations of Punnoose et al. revealed cytotoxicity of $\mathrm{ZnO}$ to prokaryotic and eukaryotic cells in higher concentrations [26]. It could be shown that the lethal concentration for zebra fish embryos is in a range of $50-100 \mathrm{mg} / \mathrm{L} \mathrm{ZnO}$ nanoparticles and a lower concentration $(1-25 \mathrm{mg} / \mathrm{L})$ was accompanied with a retarded hatching of the embryos [27].

\section{Conclusion}

The antibacterial efficacy and washing stability of coated polyester samples depends on the composition of the coating solution. Particles of $\mathrm{ZnO}$ in the range of 50 - $300 \mathrm{~nm}$ demonstrate better results with regard to antibacterial efficacy after different washing cycles whereas nanoparticles with a size of $10 \mathrm{~nm}$ show improved optical appearance. Using the binder Impranil DLU for coating, slightly enhanced activity against Staphylococcus aureus and Klebsiella pneumoniae is obtained compared to the binder Baybond PU. Coating on an industrial scale with a foulard machine requires a finely dispersed $\mathrm{ZnO}$ solution for coating to avoid sedimentation of the nanoparticles. Because of the incompatibility of the zinc oxide dispersion with Impranil DLU the binder Baybond PU represents a favorable alternative for the developed coating system. Pretreatment of the textiles with CCVD-technique to generate a hydrophilic nano layer of hydroxyl terminated silicon network on the textile surface has no influence on the antibacterial efficacy and washing stability of the coating. But using CCVD the applied amount of $\mathrm{ZnO}$ can be increased on a foulard machine emphasizing the use of CCVD for industrial scale. 

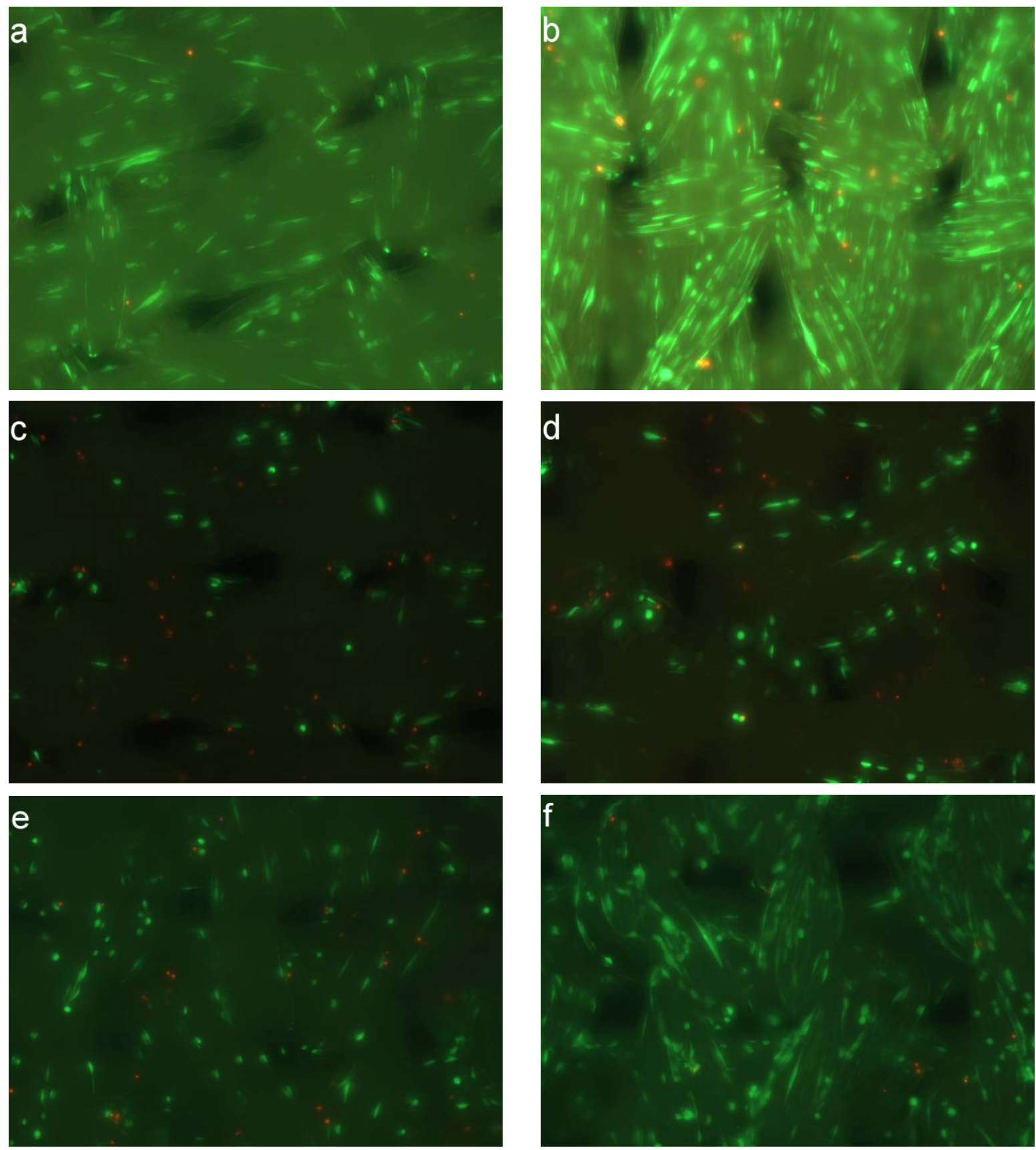

Figure 6. Cell viability testing of coated polyester samples using a FDA/GelRed® live/dead assay (a) (c) (e) cell incubating for 1 day; (b) (d) (f) cell incubating for 4 days; green fluorescence: living cells; red fluorescence: dead cell nuclei); (a) (b) polyester control without coating; (c) (d) coating with solution of $0.5 \% \mathrm{ZnO}$ (IBUtec dispersion, amount of about $50 \mu \mathrm{g}$ $\mathrm{ZnO} / \mathrm{cm}^{2}$ textile); (e) (f) coating with solution of $0.25 \% \mathrm{ZnO}$ (IBUtec dispersion, amount of about $20 \mu \mathrm{ZnO} / \mathrm{cm}^{2}$ textile).

A $\mathrm{ZnO}$ concentration up to $20 \mu \mathrm{g} \mathrm{ZnO} / \mathrm{cm}^{2}$ is found to exhibit suitable antibacterial effect and requires cytocompatibility. Further studies in order to enhance washing stability of the antibacterial coated textiles have do be done.

\section{Funding}

This work was supported by the Federal Ministry of Education and Research (grant no. 03WKBR7G). 


\section{Acknowledgements}

We thank Dr. M. Schweder for SEM and EDX measurements and U. Gitter for the CCVD-treatment.

\section{References}

[1] Hsu, B.B. and Klibanov, A.M. (2011) Light-Activated Covalent Coating of Cotton with Bactericidal Hydrophobic Polycations. Biomacromolecules, 12, 6-9. http://dx.doi.org/10.1021/bm100934c

[2] Liang, J., Chen, Y., Barnes, K., Wu, R., Worley, S.D. and Huang T.S. (2006) N-Halamine/Quat Siloxane Copolymers for Use in Biocidal Coatings. Biomaterials, 27, 2495-2501. http://dx.doi.org/10.1016/j.biomaterials.2005.11.020

[3] Gao, Y. and Cranston, R. (2008) Recent Advances in Antimicrobial Treatments of Textiles. Textile Research Journal, 78, 60-72. http://dx.doi.org/10.1177/0040517507082332

[4] Mahltig, B., Fiedler, D. and Böttcher, H. (2004) Antimicrobial Sol-Gel Coatings. Journal of Sol-Gel Science and Technology, 32, 219-222. http://dx.doi.org/10.1007/s10971-004-5791-7

[5] Radetić, M., Ilić, V., Vodnik, V., Dimitrijević, S., Jovančić, P., Šaponjić, Z. and Nedeljković, J.M. (2008) Antibacterial Effect of Silver Nanoparticles Deposited on Corona-Treated Polyester and Polyamide Fabrics. Polymers for Advanced Technologies, 19, 1816-1821. http://dx.doi.org/10.1002/pat.1205

[6] Ilić, V., Šaponjić, Z., Vodnik, V., Lazovicić, S., Dimitrijević, S., Jovančić, P., Nedeljković, J.M. and Radetić, M. (2010) Bactericidal Efficiency of Silver Nanoparticles Deposited onto Radio Frequency Plasma Pretreated Polyester Fabrics. Industrial \& Engineering Chemistry Research, 49, 7287-7293. http://dx.doi.org/10.1021/ie1001313

[7] Mejía, M.I., Restrepo, G., Marín, J.M., Sanjines, R., Pulgarín, C., Mielczarski, E., Mielczarski, J. and Kiwi, J. (2010) Magnetron-Sputtered Ag Surfaces. New Evidence for the Nature of the Ag Ions Intervening in Bacterial Inactivation. ACS Applied Materials \& Interfaces, 2, 230-235. http://dx.doi.org/10.1021/am900662q

[8] Torres, A., Ruales, C., Pulgarin, C., Aimable, A., Bowen, P., Sarria, V. and Kiwi, J. (2010) Innovative High-SurfaceArea CuO Pretreated Cotton Effective in Bacterial Inactivation under Visible Light. ACS Applied Materials \& Interfaces, 2, 2547-2552. http://dx.doi.org/10.1021/am100370y

[9] Chen, Z., Luo, J. and Sun, Y. (2007) Biocidal Effiacy, Biofilm-Controlling Function, and Controlled Release Effect of Chloromelamine-Based Bioresponsive Fibrous Materials. Biomaterials, 28, 1597-1609. http://dx.doi.org/10.1016/j.biomaterials.2006.12.001

[10] Ringot, C., Sol, V., Barrière, M., Saad, N., Bressollier, P., Granet, R., Couleaud, P., Frochot, C. and Krausz, P. (2011) Triazinyl Porphyrin-Based Photoactive Cotton Fabrics: Preparation, Characterization, and Antibacterial Activity. Biomacromolecules, 12, 1716-1723. http://dx.doi.org/10.1021/bm200082d

[11] El-tahlawy, K.F., El-bendary, M.A., Elhendawy, A.G. and Hudson, S.M. (2005) The Antimicrobial Activity of Cotton Fabrics Treated with Different Crosslinking Agents and Chitosan. Carbohydrate Polymers, 60, 421-430. http://dx.doi.org/10.1016/j.carbpol.2005.02.019

[12] Alonso, D., Gimeno, M., Olayo, R., Vázquez-Torres, H., Sepúlveda-Sánchez, J.D. and Shirai, K. (2009) Cross-Linking Chitosan into UV-Irradiated Cellulose Fibers for the Preparation of Antimicrobial-Finished Textiles. Carbohydrate Polymers, 77, 536-543. http://dx.doi.org/10.1016/j.carbpol.2009.01.027

[13] Brausch, J.M. and Rand, G.M. (2011) A Review of Personal Care Products in the Aquatic Environment: Environmental Concentrations and Toxicity. Chemosphere, 82, 1518-1532. http://dx.doi.org/10.1016/j.chemosphere.2010.11.018

[14] Holdsworth, S.R. and Law, C.J. (2013) The Major Facilitator Superfamily Transporter MdtM Contributes to the Intrinsic Resistance of Escherichia coli to Quaternary Ammonium Compounds. Journal of Antimicrobial Chemotherapy, 68, 831-839. http://dx.doi.org/10.1093/jac/dks491

[15] Braga, T.M., Marujo, P.E., Pomba, C. and Lopes, M.F.S. (2011) Involvement, and Dissemination, of the Enterococcal Small Multidrug Resistance Transporter QacZ in Resistance to Quaternary Ammonium Compounds. Journal of Antimicrobial Chemotherapy, 66, 283-286. http://dx.doi.org/10.1093/jac/dkq460

[16] Ciusa, M.L., Furi, L., Knight, D., Decorosi, F., Fondi, M., Raggi, C., Coelho, J.R., Aragones, L., Moce, L., Visa, P., Freitas, A.T., Baldassarri, L., Fani, R., Viti, C., Orefici, G., Martinez, J.L., Morrissey, I. and Oggioni, M.R. (2012) A Novel Resistance Mechanism to Triclosan That Suggests Horizontal Gene Transfer and Demonstrates a Potential Selective Pressure for Reduced Biocide Susceptibility in Clinical Strains of Staphylococcus aureus. International Journal of Antimicrobial Agents, 40, 210-220. http://dx.doi.org/10.1016/j.ijantimicag.2012.04.021

[17] Vigneshwaran, N., Kumar, S., Kathe, A.A., Varadarajan, P.V. and Prasad, V. (2006) Functional Finishing of Cotton Fabrics Using Zinc Oxide-Soluble Starch Nanocomposites. Nanotechnology, 17, 5087-5095. http://dx.doi.org/10.1088/0957-4484/17/20/008

[18] Rajendran, R., Balakumar, C., Ahammed, H.A.M., Jayakumar, S., Vaideki, K. and Rajesh, E. (2010) Use of Zinc Ox- 
ide Nano Particles for Production of Antimicrobial Textiles. International Journal of Engineering Science and Technology, 2, 202-208.

[19] Kathirvelu, S., D’Souza, L. and Dhurai, B. (2008) A Comparative Study of Multifunctional Finishing of Cotton and P/C Blended Fabrics Treated with Titanium Dioxide/Zinc Oxide Nanoparticles. Indian Journal of Science and Technology, 1, 1-12. http://www.indjst.org/index.php/indjst/article/view/29597

[20] Liu, Y., He, L., Mustapha, A., Li, H., Hu, Z.Q. and Lin, M. (2009) Antibacterial Activities of ZnO Nanoparticles against Escherichia coli O157:H7. Journal of Applied Microbiology, 107, 1193-1201. http://dx.doi.org/10.1111/j.1365-2672.2009.04303.x

[21] Xie, Y., He, Y., Irwin, P.L., Jin, T. and Shi, X. (2011) Antibacterial Activity and Mechanism of Action of Zinc Oxide Nanoparticles against Campylobacter jejuni. Applied and Environmental Microbiology, 77, 2325-2331. http://dx.doi.org/10.1128/AEM.02149-10

[22] Nair, S., Sasidharan, A., Divya Rani, V.V., Menon, D., Nair, S., Manzoor, K. and Raina, S. (2009) Role of Size Scale of ZnO Nanoparticles and Microparticles on Toxicity toward Bacteria and Osteoblast Cancer Cells. Journal of Materials Science: Materials in Medicine, 20, 235-241. http://dx.doi.org/10.1007/s10856-008-3548-5

[23] Brayner, R., Ferrari-Iliou, R., Brivois, N., Djediat, S., Benedetti, M.F. and Fievet, F. (2006) Toxicological Impact Studies Based on Escherichia coli Bacteria in Ultrafine ZnO Nanoparticles Colloidal Medium. Nano Letters, 6, 866870. http://dx.doi.org/10.1021/nl052326h

[24] Wiegand, C., Heinze, T. and Hipler, U.C. (2009) Comparative in Vitro Study on Cytotoxicity, Antimicrobial Activity, and Binding Capacity for Pathophysiological Factors in Chronic Wounds of Alginate and Silver-Containing Alginate. Wound Repair and Regeneration, 17, 511-521. http://dx.doi.org/10.1111/j.1524-475X.2009.00503.X

[25] Zhang, L., Jiang, Y., Ding, Y., Povey, M. and York, D. (2007) Investigation into the Antibacterial Behaviour of Suspensions of ZnO Nanoparticles (ZnO Nanofluids). Journal of Nanoparticle Research, 9, 479-489. http://dx.doi.org/10.1007/s11051-006-9150-1

[26] Reddy, K.M., Feris, K., Bell, J., Wingett, D.G., Hanley, C. and Punnoose, A. (2007) Selective Toxicity of Zinc Oxide Nanoparticles to Prokaryotic and Eukaryotic Systems. Applied Physics Letters, 90, Article ID: 213902. http://dx.doi.org/10.1063/1.2742324

[27] Bai, W., Zhang, Z., Tian, W., He, X., Ma, Y., Zhao, Y. and Chai, Z. (2010) Toxicity of Zinc Oxide Nanoparticles to Zebrafish Embryo: A Physicochemical Study of Toxicity Mechanism. Journal of Nanoparticle Research, 12, 16451654. http://dx.doi.org/10.1007/s11051-009-9740-9 